\title{
Toxoplasma gondii seropositivity and the associated risk factors in sheep and pregnant women in El-Minya Governorate, Egypt
}

\author{
Abdelbaset E. Abdelbaset ${ }^{1}$, Maha I. Hamed ${ }^{2}$, Mostafa F. N. Abushahba ${ }^{3,4}$, Mohamed S. Rawy ${ }^{5}$, Amal S. M. Sayed ${ }^{3}$ and \\ Jeffrey J. Adamovicz ${ }^{4}$ \\ 1. Department of Animal Medicine (Clinical Laboratory Diagnosis), Faculty of Veterinary Medicine, Assiut University, \\ 71526-Assiut, Egypt; 2. Department of Animal Medicine (Infectious Diseases), Faculty of Veterinary Medicine, Assiut \\ University, 71526 Assiut, Egypt; 3. Department of Zoonoses, Faculty of Veterinary Medicine, Assiut University, 71526 \\ Assiut, Egypt; 4. Department of Veterinary Pathobiology, College of Veterinary Medicine, University of Missouri, \\ Columbia, Missouri 65211-5130, USA; 5. Department of Theriogenology, Faculty of Veterinary Medicine, Minia University, \\ El-Minya, Egypt. \\ Corresponding author: Jeffrey J. Adamovicz, e-mail: adamoviczj@missouri.edu \\ Co-authors: AEA: abdelbaset2006@hotmail.com, MIH: mahohzero@gmail.com, MFNA: mateya@aun.edu.eg, \\ MSR: sadawyvet84@yahoo.com, ASMS: amalsayed73@yahoo.com \\ Received: 06-09-2019, Accepted: 13-11-2019, Published online: 09-01-2020
}

doi: www.doi.org/10.14202/vetworld.2020.54-60 How to cite this article: Abdelbaset AE, Hamed MI, Abushahba MFN, Rawy MS, Sayed ASM, Adamovicz JJ (2020) Toxoplasma gondii seropositivity and the associated risk factors in sheep and pregnant women in El-Minya Governorate, Egypt, Veterinary World, 13(1): 54-60.

\begin{abstract}
Background and Aim: The cosmopolite protozoan, Toxoplasma gondii, has a significant economic and medical impact. Cats traditionally play a predominant role in the disease maintenance cycle; however, humans can be infected as a result of milk and meat consumption of Toxoplasma-infected livestock. In addition, infected pregnant women, even symptomless, can pass the disease to their unborn fetus. The limited clinical records and absence of specific national educational programs in countries like Egypt underscore the need for periodic toxoplasmosis disease evaluation. Here, we identified $T$. gondii seroprevalence among sheep and pregnant women and the associated risk factors in El-Minya Governorate, Egypt.
\end{abstract}

Materials and Methods: Using peripheral blood, we detected T. gondii-specific antibodies in 151 sheep and 96 pregnant women sera from El-Minya Governorate using latex agglutination and indirect enzyme-linked immunosorbent assay. The impact of different environmental and behavioral risk factors identified with in-person interviews and serology results on acquiring toxoplasmosis was statistically analyzed.

Results: The overall toxoplasmosis seroprevalence was $39.1 \%$ and $22.9 \%$ in sheep and pregnant women, respectively. Significantly higher seroprevalence was correlated with increasing sheep age and geographical location. Nonetheless, no statistical significance was found based on abortion history and pregnancy status of the examined sheep. Exposure factors important for pregnant women included pregnancy trimester, contact with cats, and the habit of eating undercooked sheep meat, which all had a statistically significant association with Toxoplasma seropositivity.

Conclusion: The current study confirms increased antibodies against toxoplasmosis in both sheep and pregnant women in El-Minya Governorate and a clear association between women's age, contact with cats, and the habit of eating undercooked sheep meat and seroreactivity to $T$. gondii. These results strongly suggest the need for a more comprehensive epidemiological study and public health awareness education for toxoplasmosis.

Keywords: abortion, Egypt, risk factors, sheep, toxoplasmosis, zoonoses.

\section{Introduction}

Toxoplasmosis is a parasitic zoonosis caused by a cosmopolite protozoon, Toxoplasma gondii, one of the most ubiquitous parasites among humans and warm-blooded animals. It was reported that $30-50 \%$ of the human world population have been found infected with the disease, making $T$. gondii the most prevalent worldwide zoonosis [1]. The infection can be acquired through the ingestion of contaminated food or water with sporulated oocysts, consumption of undercooked

Copyright: Abdelbaset, et al. Open Access. This article is distributed under the terms of the Creative Commons Attribution 4.0 International License (http://creativecommons.org/licenses/ by/4.0/), which permits unrestricted use, distribution, and reproduction in any medium, provided you give appropriate credit to the original author(s) and the source, provide a link to the Creative Commons license, and indicate if changes were made. The Creative Commons Public Domain Dedication waiver (http:// creativecommons.org/publicdomain/zero/1.0/) applies to the data made available in this article, unless otherwise stated. meat harboring tissue cysts, and transplacental transmission of tachyzoites from mother to fetus [2]. In general, toxoplasmosis in humans is asymptomatic; however, postnatal infection results in fatal encephalitis in immunodeficient patients such as those with AIDS or organ transplant recipients [3]. Congenital toxoplasmosis, in addition, may cause spontaneous abortion, premature birth, and stillbirth in pregnant women who become infected for the $1^{\text {st }}$ time $[4,5]$. In sheep, T. gondii infection is responsible for economic and reproductive problems, resulting in abortion and stillbirth [6]. In Egypt, the seroprevalence of T. gondii infection in pregnant women has been reported to range between $11.8 \%$ and $67.6 \%$ [7-12] and between $4.1 \%$ and $100 \%$ in sheep $[8,11,13-15]$.

In spite of the substantial medical and economic implications of $T$. gondii in humans and animals, the epidemiological status of this parasite in several 
localities in Egypt, such as El-Minya Governorate, requires additional study. While the significance of this disease is important worldwide as calculated by disability-adjusted life years, the situation in Egypt is unclear. In particular, the number of both human and animal abortion events associated with toxoplasmosis is not readily available. The overall economic impact effect on domestic livestock associated with toxoplasmosis is also unknown. Both of these variables have been determined in other countries, leading to better public health policies and practices. Therefore, the collection of critical data to better understand the impact of toxoplasmosis in Egypt is a significant unmet need.

The lack of current epidemiological data led us to perform this study to identify the seroprevalence of $T$. gondii infection among pregnant women and sheep and to assess the associated risk factors in El-Minya Governorate.

\section{Materials and Methods}

\section{Ethical approval and informed consent}

All procedures performed in studies involving human participants were in accordance with the ethical standards of Assiut University Institutional Ethical Committee. All pregnant women were informed about the study objectives, methodology, voluntary participation, and personal information confidentiality. Pregnant women were not literate enough to participate in a written consent and none of them agreed to sign a written consent due to the Egyptian culture. Therefore, verbal consents were taken from all adults and parental consents were attained before the participation of those under the age of 18. All animals were handled in compliance with the Assiut University regulatory rules for animal research. Furthermore, sheep samples and data were collected after the agreement of the owners. The study was approved by Assiut University Institutional Ethical Committee.

\section{Study area}

The present study was conducted between 2017 and 2018 in El-Minya Governorate, one of the agricultural governorates which is located $\sim 245 \mathrm{~km}$ south of the capital Cairo (Figure-1). At-risk population is 5.8 million and the residents rear sheep in small herds with limited range. The study focused on two districts (Dayr Mawas and Matay) which belong to El-Minya Governorate (Figure-1).

\section{Sample size determination}

Because this is the first cross-sectional study to determine the seroprevalence of toxoplasmosis in sheep in El-Minya, to determine the sample size, we have used survey data reported previously in one of the nearest Egyptian governorates, El-Fayoum, where the seroprevalence in sheep using immunoglobulin $\mathrm{G}$ enzyme-linked immunosorbent assay (IgG ELISA)

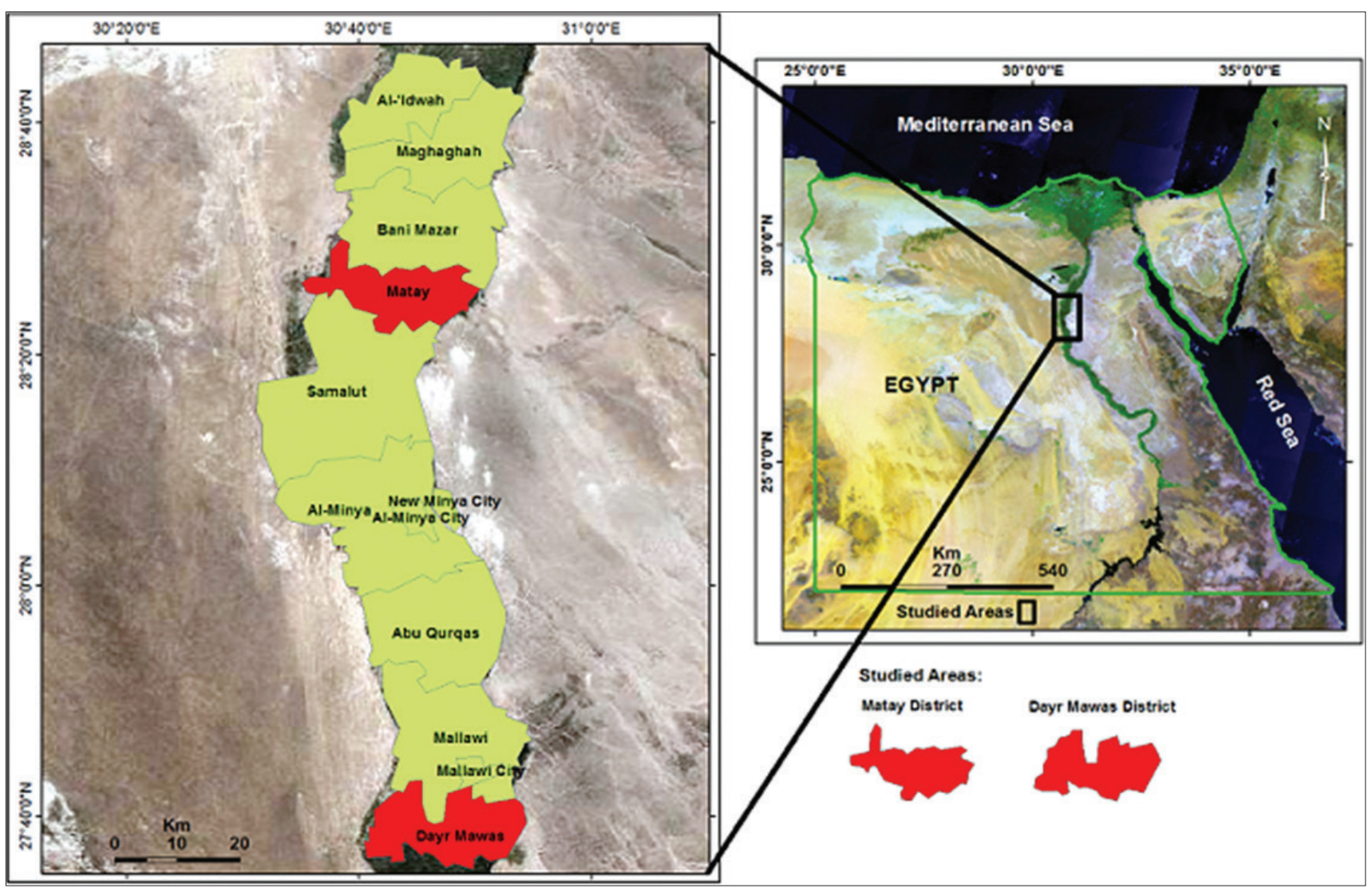

Figure-1: Satellite image of Egypt showing the general study locations. The survey covered different villages in Dayr Mawas and Matay districts, El-Minya Governorate, Egypt. [Source: The map was downloaded from http://www.gadm.org. ArcGIS 10.5 Desktop Software (Environmental Systems Research Institute, Inc., Redlands, California, USA) and GIMP 2.8.10 program (https://www.gimp.org/) were utilized in map processing]. 
was found to be $98.4 \%$ [8]. We have selected that area for comparison due to similarities in the climatic parameters [16]. In the current survey, a sample size range of 24-42 sheep was a minimum based on the equation $\left(n=Z^{2} \times P \times q / d^{2}\right)$, where " $n$ " is the minimal calculated sample size and " $Z$ " is a constant equal to 1.96 at $5 \%$ type 1 error or 2.58 at $1 \%$ type 1 error [17].

\section{Animal sera}

A total of 151 serum samples were obtained from female sheep (mean age $3.9 \pm 1.9$ years), from different villages belong to Dayr Mawas and Matay districts. Blood samples were collected by jugular vein puncture using sterile needles and Vacutainer tubes. Sample identity and relevant data, such as age, locality, pregnancy status, and abortion history, were recorded. Blood samples were immediately transported on ice to the laboratory at Animal Medicine Department, Faculty of Veterinary Medicine, Assiut University, and then centrifuged at $1800 \times \mathrm{g}$ for $15 \mathrm{~min}$ to obtain sera [18]. Sera were kept in Eppendorf tubes and stored at $-20^{\circ} \mathrm{C}$ until analysis.

\section{Human sera}

A total of 96 pregnant women (mean age $26.3 \pm 6.6$ years) were included in this study. Using a sterile syringe and needle, $5 \mathrm{~mL}$ of blood was taken by an experienced laboratory technician from each study participant. Blood samples were properly handled as described earlier. Participant data including name, age, locality, pregnancy, parity, exposure to soil, contact with cats, and consumption of undercooked meat for each participant were collected.

\section{Serological assays}

Serum samples were screened using the latex agglutination test (LAT). LAT-positive samples were confirmed by IgG ELISA.

\section{$L A T$}

LAT was performed according to the kit manufacturer's instructions (Toxo Latex Kit, CamTech Medical, UK). Briefly, $40 \mu \mathrm{L}$ serum samples were placed on the kit agglutination slide. One drop of each negative and positive control sera was included for each assay. Twenty microliters of Toxo latex reagent were added to $40 \mu \mathrm{L}$ sera samples into separate circles and mixed well with stirring sticks; then, the mixture was slowly rotated for $6 \mathrm{~min}$. Samples were considered positive when agglutination was observed, which indicates that the concentration of antibody is equal to or more than $4 \mathrm{IU} / \mathrm{mL}$.

\section{$\operatorname{IgG}$ ELISA}

Positive results observed by LAT were further confirmed using a commercial Toxoplasma IgG ELISA kit (Atlas Medical Company, UK). ELISA was performed following the manufacturer's instructions. Antihuman enzyme conjugate was used for human sera, and anti-multispecies horseradish peroxidase conjugate was used (IDvet Innovative Diagnostics, Grabels, France) for sheep samples. The optical density was measured at $450 \mathrm{~nm}$ using Stat Fax 2100 Microplate Reader (Awareness Technology, Inc., FL, USA).

\section{Statistical analysis}

To measure the impact of each factor individually on the occurrence of the disease in sheep (i.e., age, locality, pregnancy, and abortion history) and pregnant women (i.e., age, locality, trimester of pregnancy, parity, exposure to soil, contact with cats, and consumption of undercooked meat), Fisher's exact test in GraphPad Prism 6.0 software (GraphPad Software, Inc., La Jolla, CA, USA) was used. Odds ratio (OR) and $95 \%$ confidence intervals were calculated. $p<0.05$ was considered statistically significant.

\section{Results}

Initial screening of sera by LAT detected a toxoplasmosis seropositive rate of $42.4 \%$ (64 of 151) and $30.2 \%$ (29 of 96) in sheep and humans, respectively. ELISA test results further confirmed that $92.2 \%$ (59 of 64) of the LAT-positive reactor sheep and $75.9 \%$ (22 of 29) of the LAT-positive reactor pregnant women had $T$. gondii IgG antibodies (Table-1).

The overall seroprevalence of $T$. gondii among sheep was $39.1 \%$. Among the analyzed variables in this study, age of the examined sheep and the sampling locality were statistically significant $(p<0.0001$, for both variables). A higher prevalence of $T$. gondii was detected in the 1-2-year-old group $(66.7 \%$, OR=75, $95 \%$ confident interval $[\mathrm{CI}]=4.0-1431)$ followed by $40.5 \% \quad(\mathrm{OR}=27,95 \% \mathrm{CI}=1.6-454) \quad$ in $>2$-year-old age group; conversely, we did not detect any positive cases in $<1$-year age group. The prevalence of T. gondii was $57.4 \%$ in Matay $(\mathrm{OR}=14,95 \% \mathrm{CI}=5.1$ 38 ) in comparison to $8.8 \%$ in Dayr Mawas $(\mathrm{OR}=0.07$, $95 \% \mathrm{CI}=0.03-0.2)$. There was no significant effect $(p>0.05)$ observed for abortion history and pregnancy status of the examined sheep (Table-2).

In pregnant women, the overall prevalence of T. gondii was $22.9 \%$. Regarding the major risk factors associated with $T$. gondii seroreactivity, the pregnancy trimester showed statistically significant association

Table-1: Toxoplasmosis seroprevalence rate in sheep and humans.

\begin{tabular}{|c|c|c|c|c|c|c|}
\hline \multirow[t]{2}{*}{ Species } & \multicolumn{3}{|c|}{ Latex agglutination test (screening) } & \multicolumn{3}{|c|}{$\begin{array}{l}\text { Enzyme-linked immunosorbent assay } \\
\text { (confirmation) }\end{array}$} \\
\hline & $\begin{array}{c}\text { Number of } \\
\text { tested }\end{array}$ & $\begin{array}{c}\text { Positive number } \\
(\%)\end{array}$ & $\begin{array}{c}\text { Negative number } \\
(\%)\end{array}$ & $\begin{array}{c}\text { Number of } \\
\text { tested }\end{array}$ & $\begin{array}{l}\text { Positive number } \\
(\%)\end{array}$ & $\begin{array}{c}\text { Negative number } \\
(\%)\end{array}$ \\
\hline Sheep & 151 & $64(42.4)$ & $87(57.6)$ & 64 & $59(92.2)$ & $5(7.8)$ \\
\hline Human & 96 & $29(30.2)$ & $67(69.8)$ & 29 & $22(75.9)$ & $7(24.1)$ \\
\hline
\end{tabular}


Table-2: Seroprevalence of Toxoplasma gondii antibody and the associated risk factors in sheep.

\begin{tabular}{|c|c|c|c|c|c|}
\hline \multirow[t]{2}{*}{ Factor } & \multirow[t]{2}{*}{ Number tested } & \multicolumn{2}{|c|}{ Seroprevalence } & \multirow{2}{*}{$\begin{array}{c}\text { Odds ratio ( } 95 \% \\
\text { confidence interval) }\end{array}$} & \multirow[t]{2}{*}{ p-value } \\
\hline & & $\begin{array}{c}\text { Positive number } \\
(\%)\end{array}$ & $\begin{array}{c}\text { Negative number } \\
(\%)\end{array}$ & & \\
\hline \multicolumn{6}{|l|}{ Age (years) } \\
\hline$<1$ & 19 & $0(0)$ & $19(100)$ & Reference & $<0.0001$ \\
\hline $1-2$ & 21 & $14(66.7)$ & $7(33.3)$ & $75(4.0-1431)$ & \\
\hline$>2$ & 111 & $45(40.5)$ & $66(59.5)$ & $27(1.6-454)$ & \\
\hline \multicolumn{6}{|l|}{ Locality } \\
\hline Matay & 94 & $54(57.4)$ & $40(42.5)$ & $14(5.1-38)$ & $<0.0001$ \\
\hline Dayr Mawas & 57 & $5(8.8)$ & $52(91.2)$ & $0.07(0.03-0.2)$ & \\
\hline \multicolumn{6}{|l|}{ Pregnancy } \\
\hline Pregnant & 84 & $38(45.2)$ & $46(54.8)$ & $1.81(0.9-3.5)$ & 0.09 \\
\hline Non-pregnant & 67 & $21(31.3)$ & $46(68.7)$ & $0.55(0.3-1.1)$ & \\
\hline \multicolumn{6}{|l|}{ Abortion history } \\
\hline Yes & 3 & $2(66.7)$ & $1(33.3)$ & $3.2(0.3-36)$ & 0.6 \\
\hline No & 148 & $57(38.5)$ & $91(61.5)$ & $0.3(0.03-3.5)$ & \\
\hline
\end{tabular}

Table-3: Factors associated with Toxoplasma gondii seropositivity among the pregnant women.

\begin{tabular}{|c|c|c|c|c|c|}
\hline \multirow[t]{2}{*}{ Factor } & \multirow{2}{*}{$\begin{array}{l}\text { Number of } \\
\text { tested }\end{array}$} & \multicolumn{2}{|c|}{ Seroprevalence } & \multirow{2}{*}{$\begin{array}{c}\text { Odds ratio ( } 95 \% \\
\text { confidence interval) }\end{array}$} & \multirow[t]{2}{*}{ p-value } \\
\hline & & $\begin{array}{c}\text { Positive number } \\
(\%)\end{array}$ & $\begin{array}{c}\text { Negative number } \\
(\%)\end{array}$ & & \\
\hline \multicolumn{6}{|l|}{ Age (years) } \\
\hline $17-19$ & 12 & $1(8.3)$ & $11(91.7)$ & Reference & 0.7 \\
\hline $20-24$ & 32 & $9(28.1)$ & $23(71.9)$ & $4.3(0.5-38)$ & \\
\hline $25-29$ & 29 & $6(20.7)$ & $23(79.3)$ & $2.9(0.3-27)$ & \\
\hline $30-35$ & 15 & $4(26.7)$ & $11(73.3)$ & $4(0.4-42)$ & \\
\hline$>35$ & 8 & $2(25)$ & $6(75)$ & $3.7(0.3-49)$ & \\
\hline \multicolumn{6}{|l|}{ Locality } \\
\hline Matay & 46 & $13(28.3)$ & $33(71.7)$ & $1.8(0.7-4.7)$ & 0.3 \\
\hline Dayr Mawas & 50 & $9(18)$ & $41(82)$ & $0.6(0.2-1.5)$ & \\
\hline \multicolumn{6}{|l|}{ Pregnancy } \\
\hline $1^{\text {st }}$ trimester & 16 & $0(0)$ & $16(100)$ & Reference & 0.02 \\
\hline $2^{\text {nd }}$ trimester & 28 & $10(35.7)$ & $18(64.3)$ & $19(1.0-345)$ & \\
\hline $3^{\text {rd }}$ trimester & 52 & $12(23.1)$ & $40(76.9)$ & $10(0.6-182)$ & \\
\hline \multicolumn{6}{|l|}{ Parity } \\
\hline One time & 28 & $3(10.7)$ & $25(89.3)$ & $0.3(0.08-1.1)$ & 0.1 \\
\hline Two times or more & 68 & $19(27.9)$ & $49(72.1)$ & $3.2(0.9-12)$ & \\
\hline \multicolumn{6}{|l|}{ Exposure to soil } \\
\hline Yes & 33 & $5(15.1)$ & $28(84.8)$ & $0.48(0.2-1.5)$ & 0.2 \\
\hline No & 63 & $17(27)$ & $46(73)$ & $2.1(0.7-6.2)$ & \\
\hline \multicolumn{6}{|l|}{ Contact with cat } \\
\hline Yes & 28 & $12(42.9)$ & $16(57.1)$ & $4.4(1.6-12)$ & 0.006 \\
\hline No & 68 & $10(14.7)$ & $58(85.3)$ & $0.2(0.08-0.6)$ & \\
\hline \multicolumn{6}{|c|}{ Consumption of undercooked mutton } \\
\hline Yes & 18 & $12(66.7)$ & $6(33.3)$ & $14(4.2-44)$ & $<0.0001$ \\
\hline No & 78 & $10(12.8)$ & $68(87.2)$ & $0.07(0.02-0.2)$ & \\
\hline
\end{tabular}

with Toxoplasma seropositivity $(\mathrm{p}=0.025)$. Pregnant women at the $2^{\text {nd }}$ trimester were found to have the highest odds of exposure ( $\mathrm{OR}=19,95 \% \mathrm{CI}=1-345)$ followed by those in the $3^{\text {rd }}$ trimester $(\mathrm{OR}=10,95 \%$ $\mathrm{CI}=0.6-182)$. In addition, toxoplasmosis seropositivity was found significant $(p=0.006)$ in relation to contact of the sampled women with cats and the odds of exposure were found higher in those who had contact with cats $(\mathrm{OR}=4.4,95 \% \mathrm{CI}=1.6-12)$ compared to those without previous contact with cats $(\mathrm{OR}=0.2$, $95 \% \mathrm{CI}=0.08-0.6)$. Moreover, the study showed that the habit of eating undercooked sheep had a significant effect on Toxoplasma seropositivity $(\mathrm{p}<0.0001)$. Higher odds of exposure were found among pregnant women with a habit of consumption of undercooked mutton $(\mathrm{OR}=14,95 \% \mathrm{CI}=4.2-44)$ compared to those without $(\mathrm{OR}=0.07,95 \% \mathrm{CI}=0.02-0.2)$. However, there was no significant association between age $(\mathrm{p}=0.7)$, locality $(\mathrm{p}=0.3)$, parity $(\mathrm{p}=0.1)$, or exposure to soil $(\mathrm{p}=0.2)$ and $T$. gondii seropositivity (Table-3).

\section{Discussion}

Sheep being important reservoirs for many pathogens with public health significance, our research group explored the epidemiological role of this small ruminant in toxoplasmosis. We have recently shown the presence of bacterial-specific antibodies against Coxiella burnetii and brucellae in sheep and humans residing in El-Minya Governorate with subsequent analysis of the associated risk factors $[18,19]$. Limited 
epidemiological data regarding toxoplasmosis in El-Minya Governorate warranted more research. In the current study, we examined toxoplasmosis as a serious foodborne infection that might affect pregnant women.

Our survey demonstrated a $T$. gondii seroprevalence of $39.1 \%$ in the examined sheep in El-Minya Governorate. This is the first report regarding toxoplasmosis in sheep in El-Minya Governorate, Egypt, and the findings are comparable with other regions in Egypt. By comparison, the current seroprevalence of T. gondii reported among sheep was similar to that in a previous survey conducted in six Egyptian governorates (Kafr El-sheikh, Matrouh, Giza, Menoufia, Sohag, and Qena), in which the seroprevalence was $37.7 \%$ [14]. Our seroreactivity results were higher than those reported in a recent study (2018) conducted in four governorates (Cairo, Giza, Dakahlia, and Sharkia), in which the seroprevalence ranged between $4.1 \%$ and $26 \%$ [15]. Conversely, T. gondii seroprevalence in sheep was lower in El-Minya than those observed in the previous studies; $98.4 \%$ at El-Fayoum, $51.8 \%$ in Menoufia and Gharbiya, and $41.7 \%$ in Cairo $[8,11,13]$, respectively. These aforementioned differences in seroprevalence may be due to variations in climatic conditions, serological assays used, sample size, breed of sheep, place, and time of sampling [14,20].

Among the evaluated variables, the locality represented one of the risk factors associated with Toxoplasma infection. Higher toxoplasmosis seropositivity $(\mathrm{p}<0.0001)$ was observed in Matay $(57.4 \%$ in 94 sheep) compared to that in Dayr Mawas $(8.8 \%$ in 57 sheep). The significant difference could be attributed to two variables including the difference in the sample size recruited from each district as well as the access frequency of infected cats to sheep pens and grazing areas. In addition, the seroprevalence of infection was significantly $(p<0.0001)$ higher in adult sheep than juveniles. This confirms the previous investigations showing higher rates of exposure to toxoplasmosis infection with increasing age of sheep [11,20-26]. Conversely, no statistically significant effect was observed in relation to abortion history or pregnancy status of the examined sheep and toxoplasmosis.

Indeed, little attention has been devoted to toxoplasmosis surveillance, prevention, and/or treatment in El-Minya. Therefore, we further explored the seroprevalence of $T$. gondii in pregnant women in this area. The overall prevalence was $22.9 \%$ in our study, which was lower than those reported in some localities in Egypt; Sharkia (51.5\%), El-Fayoum (45.8\%), Menoufia (67.5\%), $50.8 \%$ (El-Minya), $30.2 \%$ in six governorates (Alexandria, Beheira, Gharbia, Menoufia, Qalyoubia, and Fayoum), and $33.79 \%$ in Menoufia and Gharbiya [7-12], respectively. This fluctuation in toxoplasmosis prevalence among different studies could have been related to environmental conditions, geographical location, humidity, and age distribution among the study population. The incidence of toxoplasmosis infection was previously reported to be higher in humid and warmer climates [27].

In the present study, an increase in Toxoplasma seropositivity was associated with increased age of pregnant women. The age effect was insignificant; however, higher odds of exposure in pregnant women of 20 years old and above were observed compared to those of 17-19-year-old group. This observation was consistent with other studies [11,28,29] which could be attributed to the increased odds of infection as age increases.

The impact of two obstetrical factors, namely, parity and gestational age, on acquiring toxoplasmosis in pregnant women was also assessed. Among the two variables, gestational age of the pregnant women had a significant influence $(\mathrm{p}=0.02)$ on the toxoplasmosis seropositivity. Pregnant women in their $2^{\text {nd }}$ and $3^{\text {rd }}$ trimesters had higher odds of exposure $(\mathrm{OR}=19$, $95 \% \mathrm{CI}=1-345$ and $\mathrm{OR}=10,95 \% \mathrm{CI}=0.6-182) \mathrm{com}-$ pared to those in their $1^{\text {st }}$ trimester. In agreement to our findings, the previous studies in Saudi Arabia, Sri Lanka, and Zambia also documented higher IgG levels in the $2^{\text {nd }}$ trimester compared to the other two trimesters [30-33]. Detection of specific IgG against toxoplasmosis in all trimesters in the present investigation is alarming, especially in those in their $1^{\text {st }}$ and $3^{\text {rd }}$ trimesters. Vertical transfer of toxoplasmosis in the $1^{\text {st }}$ trimester could result in serious consequences in the fetus, whereas higher incidence rates of the parasite in babies are linked to the $3^{\text {rd }}$ trimester due to the rapid transmission pattern of the parasite in that gestational period [34]. Accordingly, routine screening for toxoplasmosis in pregnant women residing in El-Minya Governorate, Egypt, is highly recommended.

Our analysis also indicated a significant association between $T$. gondii infection in pregnant women and contact with cats ranging from $40 \%$ in Matay and $46 \%$ in Dayr Mawas. This finding was in concordance with those studies showing contact with cats as a risk factor associating human toxoplasmosis [29,35,36]. Cats, the definitive host of $T$. gondii, are a major source of infection for humans and animals due to shedding of oocysts into the environment [37]. Thus, transmission of infection can occur through drinking contaminated water, consumption of contaminated unwashed vegetables and fruits [2]. Hence, the consumption of undercooked infected ovine meat was considered a major risk factor for human infection [38]. The current data further showed that the prevalence of toxoplasmosis was significantly higher in pregnant women who consumed undercooked mutton (kabab and kofta) than those who did not. These data were consistent with those of the previous investigators who showed that consumption of mutton kabab was a significant risk factor for toxoplasmosis seropositivity in pregnant women $[8,11,39]$. In a previous study in Egypt, undercooked mutton kabab was reported to raise the incidence of toxoplasmosis with the highest percentage of Toxoplasma contamination [40]. However, 
in our retrospective study, we could not definitively determine that undercooked meat was exclusively causal for increased toxoplasmosis in women. In particular, the term undercooked meat is somewhat subjective and, therefore, may skew our data set. It is also not possible to determine if association with cats, exposure to sporulated oocysts in the environment, consumption of undercooked meat, or other food risks such as raw goat milk were the causal factor for individual infections. Therefore, we recognize the limitations of our data in this context. Nevertheless, insignificant association between locality, parity, and exposure to soil and $T$. gondii seropositivity was noted in our investigation. Gelaye et al. [41] reported similar findings with an absence of risk factors associating T. gondii infection in pregnant women in Ethiopia. Collectively, we do believe our data indicate a strong association between toxoplasmosis and undercooked meat consumption.

\section{Conclusion}

Our data indicate the exposure of both sheep and pregnant women to T. gondii, in El-Minya Governorate and the potential role of sheep in transmission of human toxoplasmosis. Special educational programs about preventive and control measures should be implemented. These would include education on the role of cats, undercooked mutton, and consumption of raw goat milk as risk factors for pregnant women. Furthermore, routine toxoplasmosis screening of the pregnant women residing El-Minya Governorate in their $1^{\text {st }}$ and $3^{\text {rd }}$ trimesters is recommended. In addition, further epidemiological investigations are required to determine the rates of toxoplasmosis in other domestic animals, including cats, and other human subgroups including immunocompromised women throughout the governorate. This additional data may be useful in determining the effect of toxoplasmosis on human abortion rates.

\section{Authors' Contributions}

AEA, MIH, MFNA, and MSR designed the study, shared in sampling, ELISA work, and data analysis. ASMS contributed to sample collection and ELISA work. JJA contributed to literature collection, data analysis, and critical editing and reviewing of the manuscript. All authors wrote, edited, read, and approved the final manuscript.

\section{Acknowledgments}

We would like to thank Dr. Abdelhamid M. Salman and Dr. Wael F. Galal, Geology Department, Faculty of Science, Assiut University, Egypt, for providing the map. Sincere thanks are due to Abdelhafeez Youssef, Dayr Mawas Veterinary Hospital and Mahmoud Nagah, Samalut Veterinary Hospital, El-Minya Governorate, for helping in sample and data collection. The authors did not receive any funding for this study.

\section{Competing Interests}

The authors declare that they have no competing interests.

\section{Publisher's Note}

Veterinary World remains neutral with regard to jurisdictional claims in published map and institutional affiliation.

\section{References}

1. Flegr, J., Prandota, J., Sovičková, M. and Israili, Z.H. (2014) Toxoplasmosis--a global threat. Correlation of latent toxoplasmosis with specific disease burden in a set of 88 countries. PLoS One, 9(3): e90203.

2. Robert-Gangneux, F. and Dardé, M.L. (2012) Epidemiology of and diagnostic strategies for toxoplasmosis. Clin. Microbiol. Rev., 25(2): 264-296.

3. Weiss, L.M. and Dubey, J.P. (2009) Toxoplasmosis: A history of clinical observations. Int. J. Parasitol., 39(8): 895-901.

4. Luft, B.J., Brooks, R.G., Conley, F.K., Mccabe, R.E. and Remington, J.S. (1984) Toxoplasmic encephalitis in patients with acquired immune deficiency syndrome. JAMA, 252(7): 913-917.

5. Jones, J., Lopez, A. and Wilson, M. (2003) Congenital toxoplasmosis. Am. Fam. Physician, 67(10): 2131-2138.

6. Buxton, D. (1998) Protozoan infections (Toxoplasma gondii, Neospora caninum and Sarcocystis spp.) in sheep and goats: Recent advances. Vet. Res., 29(3-4): 289-310.

7. Ibrahim, H.M., Huang, P., Salem, T.A., Talaat, R.M., Nasr, M.I., Xuan, X. and Nishikawa, Y. (2009) Short report: Prevalence of Neospora caninum and Toxoplasma gondii antibodies in Northern Egypt. Am. J. Trop. Med. Hyg., 80(2): 263-267.

8. Ghoneim, N.H., Shalaby, S.I., Hassanain, N.A., Zeedan, G.S.G., Soliman, Y.A. and Abdalhamed, A.M. (2010) Comparative study between serological and molecular methods for diagnosis of toxoplasmosis in women and small ruminants in Egypt. Foodborne Pathog. Dis., 7(1): 17-22.

9. El Deeb, H.K., Salah-Eldin, H., Khodeer, S. and Allah, A.A. (2012) Prevalence of Toxoplasma gondii infection in antenatal population in Menoufia Governorate, Egypt. Acta Trop., 124(3): 185-191.

10. Kamal, A.M., Ahmed, A.K., Abdellatif, M.Z.M., Tawfik, M. and Hassan, E.E. (2015) Seropositivity of toxoplasmosis in pregnant women by ELISA at Minia University hospital, Egypt. Korean J. Parasitol., 53(5): 605-610.

11. Ibrahim, H.M., Mohamed, A.H., El-Sharaawy, A.A. and El-Shqanqery, H.E. (2017) Molecular and serological prevalence of Toxoplasma gondii in pregnant women and sheep in Egypt. Asian Pac. J. Trop. Med., 10(10): 996-1001.

12. El-Shqanqery, H.E., Ibrahim, H.M., Mohamed, A.H. and El-Sharaawy, A.A. (2017) Seroprevalence of Toxoplasma gondii infection and associated risk factors among asymptomatic pregnant females in Egypt. J. Egypt. Soc. Parasitol., 47(1): 93-100.

13. Shaapan, R.M., El-Nawawi, F.A. and Tawfik, M.A.A. (2008) Sensitivity and specificity of various serological tests for the detection of Toxoplasma gondii infection in naturally infected sheep. Vet. Parasitol., 153(3-4): 359-362.

14. Fereig, R.M., Mahmoud, H.Y.A., Mohamed, S.G.A., AbouLaila, M.R., Abdel-Wahab, A., Osman, S.A., Zidan, S.A., El-Khodary, S.A., Mohamed, A.E.A. and Nishikawa, Y. (2016) Seroprevalence and epidemiology of Toxoplasma gondii in farm animals in different regions of Egypt. Vet. Parasitol. Reg. Stud. Rep., 3-4: 1-6.

15. Al-Kappany, Y.M., Abbas, I.E., Devleesschauwer, B., Dorny, P., Jennes, M. and Cox, E. (2018) Seroprevalence 
of anti-Toxoplasma gondii antibodies in Egyptian sheep and goats. BMC Vet. Res., 14(1): 120.

16. Noreldin, T., Ouda, S. and Amer, A. (2016) Agro-climatic zoning in Egypt to improve irrigation water management. $J$. Water L. Dev., 31(1): 113-117.

17. Charan, J. and Biswas, T. (2013) How to calculate sample size for different study designs in medical research? Indian J. Psychol. Med., 35(2): 121-126.

18. Abushahba, M.F.N., Abdelbaset, A.E., Rawy, M.S. and Ahmed, S.O. (2017) Cross-sectional study for determining the prevalence of $\mathrm{Q}$ fever in small ruminants and humans at El Minya Governorate, Egypt. BMC Res. Notes, 10(1): 538.

19. Abdelbaset, A.E., Abushahba, M.F.N., Hamed, M.I. and Rawy, M.S. (2018) Sero-diagnosis of brucellosis in sheep and humans in Assiut and El-Minya governorates, Egypt. Int. J. Vet. Sci. Med., 6(Suppl.): S63-S67.

20. Zhang, N., Wang, S., Wang, D., Li, C., Zhang, Z., Yao, Z., Li, T., Xie, Q., Liu, S. and Zhang, H. (2016) Seroprevalence of Toxoplasma gondii infection and risk factors in domestic sheep in Henan province, central China. Parasite, 23: 53.

21. Hecker, Y.P., Moore, D.P., Manazza, J.A., Unzaga, J.M., Späth, E.J.A., Pardini, L.L., Venturini, M.C., Roberi, J.L. and Campero, C.M. (2013) First report of seroprevalence of Toxoplasma gondii and Neospora caninum in dairy sheep from Humid Pampa, Argentina. Trop. Anim. Health Prod., 45(7): 1645-1647.

22. Alvarado-Esquivel, C., Estrada-Malacón, M.A., ReyesHernández, S.O., Pérez-Ramírez, J.A., Trujillo-López, J.I., Villena, I. and Dubey, J.P. (2013) Seroprevalence of Toxoplasma gondii in domestic sheep in Oaxaca State, Mexico. J. Parasitol., 99(1): 151-152.

23. Abdallah, M.C., Kamel, M., Karima, B., Samir, A., Djamel, K., Rachid, K. and Khatima, A.O. (2019) Crosssectional survey on Toxoplasma gondii infection in cattle, sheep, and goats in Algeria: Seroprevalence and risk factors. Vet. Sci., 6(3): 63.

24. Katzer, F., Brülisauer, F., Collantes-Fernández, E., Bartley, P.M., Burrells, A., Gunn, G., Maley, S.W., Cousens, C. and Innes, E.A. (2011) Increased Toxoplasma gondii positivity relative to age in 125 Scottish sheep flocks; evidence of frequent acquired infection. Vet. Res., 42(1): 121.

25. Rahman, M., Azad, M.T.A., Nahar, L., Rouf, S.M.A., Ohya, K., Chiou, S.P., Baba, M., Kitoh, K. and Takashima, Y. (2014) Age-specificity of Toxoplasma gondii seroprevalence in sheep, goats and cattle on subsistence farms in Bangladesh. J. Vet. Med. Sci., 76(9): 1257-1259.

26. Subedi, S., Sharma, B., Singh, S. and Bindari, Y.R. (2018) Sero-prevalence of Toxoplasma gondii in sheep in different geographical regions of Nepal. Vet. Anim. Sci., 5: 7-9.

27. Tenter, A.M., Heckeroth, A.R. and Weiss, L.M. (2000) Toxoplasma gondii: From animals to humans. Int. J. Parasitol., 30(12-13): 1217-1258.

28. Sarkar, M.D., Anuradha, B., Sharma, N. and Roy, R.N. (2012) Seropositivity of toxoplasmosis in antenatal women with bad obstetric history in a tertiary-care hospital of Andhra Pradesh, India. J. Heal. Popul. Nutr., 30(1): 87-92.

29. Zemene, E., Yewhalaw, D., Abera, S., Belay, T., Samuel, A. and Zeynudin, A. (2012) Seroprevalence of Toxoplasma gondii and associated risk factors among pregnant women in Jimma town, Southwestern Ethiopia. BMC Infect. Dis., 12(1): 337.

30. Subasinghe, S., Karunaweera, N., Kaluarachchi, A., Abayaweera, C., Gunatilake, M., Ranawaka, J., Jayasundara, D. and Gunawardena, G. (2011) Toxoplasma gondii seroprevalence among two selected groups of women. Sri Lankan J. Infect. Dis., 1(1): 9.

31. Frimpong, C., Makasa, M., Sitali, L. and Michelo, C. (2017) Seroprevalence and determinants of toxoplasmosis in pregnant women attending antenatal clinic at the university teaching hospital, Lusaka, Zambia. BMC Infect. Dis., 17(1): 10 .

32. Aqeely, H., El-Gayar, E.K., Perveen Khan, D., Najmi, A., Alvi, A., Bani, I., Mahfouz, M.S., Abdalla, S.E. and Elhassan, I.M. (2014) Seroepidemiology of Toxoplasma gondii amongst pregnant women in Jazan Province, Saudi Arabia. J. Trop. Med., 2014: 913950.

33. Iddawela, D., Vithana, S.M.P. and Ratnayake, C. (2017) Seroprevalence of toxoplasmosis and risk factors of Toxoplasma gondii infection among pregnant women in Sri Lanka: A cross-sectional study. BMC Public Health, 17(1): 930.

34. Singh, S. (2003) Mother-to-child transmission and diagnosis of Toxoplasma gondii infection during pregnancy. Indian J. Med. Microbiol., 21(2): 69-76.

35. Zhou, P., Chen, Z., Li, H., Zheng, H., He, S., Lin, R. and Zhu, X. (2011) Toxoplasma gondii infection in humans in China. Parasit. Vectors, 4: 165.

36. Agmas, B., Tesfaye, R. and Koye, D.N. (2015) Seroprevalence of Toxoplasma gondii infection and associated risk factors among pregnant women in Debre Tabor, Northwest Ethiopia. BMC Res. Notes, 8(1): 107.

37. Frenkel, J.K., Dubey, J.P. and Miller, N.L. (1970) Toxoplasma gondii in cats: Fecal stages identified as coccidian oocysts. Science, 167(3919): 893-896.

38. Tenter, A.M. (2009) Toxoplasma gondii in animals used for human consumption. Mem. Inst. Oswaldo. Cruz., 104(2): 364-369.

39. Elnahas, A., Gerais, A.S., Elbashir, M.I., Eldien, E.S. and Adam, I. (2003) Toxoplasmosis in pregnant Sudanese women. Saudi Med. J., 24(8): 868-870.

40. El-Razik, K.A., El Fadaly, H.A. and Abu Elnaga, S.M. (2014) Zoonotic hazards T. Gondii viable cysts in ready to eat Egyptian meat-meals. World J. Med. Sci., 11(4): 510-517.

41. Gelaye, W., Kebede, T. and Hailu, A. (2015) High prevalence of anti-toxoplasma antibodies and absence of Toxoplasma gondii infection risk factors among pregnant women attending routine antenatal care in two hospitals of Addis Ababa, Ethiopia. Int. J. Infect. Dis., 34: 41-45.

\section{$* * * * * * * *$}

